\title{
Evaluation on Eco-Environmental Quality of Ordos Plateau
}

\author{
Ruiyan Wu, Ming Zhao, Ruiping Zhou \\ Geograghic Science College, Inner Mongolia Normal University, Hohhot, 010022, China \\ E-mail:1362607775@qq.com
}

Received 19 December 2016

Accepted 12 April 2017

\begin{abstract}
According to "Technical Criterion for Ecosystem Status Evaluation" issued by State Environmental Protection Administration, on the basis of Arcgis platform, using the comprehensive evaluation index method, the paper takes Dongsheng district as a case, selected biological richness index, vegetation coverage index, land stress index, water network denseness index and pollution load index to evaluate the quality of ecological environment. The evaluation result shows that the ecological environment quality of Dongsheng district is "normal", the degree of vegetation coverage is moderate, the biological diversity is general, and it is suitable for human to live, but sometimes exist restrictive factors limit human existence. The ecological index value increased from 52.06 of 2005 to 53.11 in 2014, and land ecological environment quality of Dongsheng district has rising trend from the overall view, but the amplitude variations in the ecological environment condition has no obvious change, land ecological environment is good, the land ecosystem structure is complete, and its function is basically perfect.
\end{abstract}

Keywords: eco-environmental assessments, ecological index, eco-environmental quality

\section{Introduction}

Eco-environment is the basis of humanity survival and development is a social economic and natural ecological system which can provide people natural resources and living environment. But ecological environment are always polluted even destroyed because of development of social and economy rapid population growth. Once polluted or destroyed, it will influence even limit the development in all aspects. We are supposed to launch scientific and comprehensive evaluation on ecological environment quality, as well as understand the causes and principle of dynamic change as ecological environment construction has become tough and urgent $\operatorname{task}[1]$.

Eco-environment quality assessment means to evaluate the advantages and disadvantages of the regional ecological environment according to selected index system[2]. According to the difference of research process and the object of the evaluation of the ecological environment, the study can be divided into 2 categories: one is evaluation on the status of the ecological environment (ecological environment quality), two is to evaluate the service function of the ecological environment (the value of the ecological environment)[3]. Ecological environmental assessment is to propose strategies and measures to reduce influence or improve ecological environmental condition after analysis, prediction and assessment of the impact human economic and social construction activities may cause. It is an important basis for prevention of ecological environment problems, rational exploitation and utilization of resources, environmental protection and sustainable economic and social development planning. Therefore, to strengthen the monitoring and evaluation of ecological environment has important practical significance to the protection of the ecological environment, management and regional sustainable development strategy[4]. 


\section{Research Area and Data Sources}

\subsection{Research Area}

Dongsheng district is located in the southwest of the Inner Mongolia Autonomous Region, Central part of the Ordos Plateau. The geographical coordinates of east longitude 109 degrees $08^{\prime} 04^{\prime \prime}-110^{\circ} 23^{\prime} 11^{\prime \prime}$, north latitude $39^{\circ} 30^{\prime} 42^{\prime \prime}-39^{\circ} 58^{\prime} 44^{\prime \prime}$, it is also one of the city's core area with its city's largest built area, the most perfect functional facilities and the highest degree of economic activity. The study area possess $2512.3 \mathrm{~km}^{2}, 60.12$ ten thousands population.

\subsection{Data Source}

Dongsheng District's Statistical Bulletin of the National Economic and Social Development (2005-2014), Dongsheng statistical yearbook (2005-2014), final database of land change survey (2005-2014), some data are provided by bureau of Statistics and meteorological administration.

\section{Framework of Evaluation Index System}

In order to carry out "Environmental Protection Law of People's Republic of China", strengthen ecological environment protection, evaluate the status and trends of ecological environment, ministry of environmental protection of the people's republic of china issued and carried "Technical Criterion for Ecosystem Status Evaluation" at 13 March, 2015.The Technical Criterion set annual evaluate index system, calculation method and classification standard to town, provincial and ecological environment status and dynamic trend.

\subsection{Evaluation Index System of Ecological Environment Condition}

Ecological environment's status evaluation is to reflect the overall state of the regional ecological environment using a composite index (ecological index). The index system includes biological richness index, vegetation coverage index, water network denseness index, land stress index, pollution load index, partial indexes are reflect biological abundance, high or low vegetation coverage, water abundance, stress intensity and pollutant loading pressure of evaluated area relatively.
3.2 Weight and Calculation Method of Evaluation Index

\subsubsection{Weight and Calculation Method of Biological Richness Index}

$I_{b i o}$ refers to the degree of abundance of biodiversity in the area being evaluated.

(1)Weight

Table 1. Weight of biological richness index

\begin{tabular}{|c|c|c|c|c|c|c|}
\hline Class & $\begin{array}{c}\text { forest } \\
\text { land }\end{array}$ & $\begin{array}{c}\text { grass } \\
\text { land }\end{array}$ & $\begin{array}{c}\text { water } \\
\text { area }\end{array}$ & $\begin{array}{c}\text { farm } \\
\text { land }\end{array}$ & $\begin{array}{c}\text { Construction } \\
\text { land }\end{array}$ & $\begin{array}{c}\text { unused } \\
\text { land }\end{array}$ \\
\hline weight & 0.35 & 0.21 & 0.28 & 0.11 & 0.04 & 0.01 \\
\hline
\end{tabular}

(2)Calculation method

$I_{b i o}=\frac{A_{b i o}\left(0.35 S_{f}+0.21 S_{g}+0.28 S_{w}+0.11 S_{a}+0.04 S_{c}+0.01 S_{u}\right)}{S_{r}}(1)$

where $A_{b i o}$ is normalization coefficients of biological richness, value is 511.2642131067. $S_{f}$ is forest land area, $S_{g}$ is grassland area, $S_{w}$ is water area, $S_{a}$ is farmland area, $S_{c}$ construction land area, $S_{u}$ unused land area, $S_{r}$ is whole area of evaluated region.

\subsubsection{Weight and Calculation Method of Vegetation Coverage Index}

Vegetation coverage index uses normalized difference vegetation index (NDVI) of regional unit area to refer to the extent of vegetation coverage.

\section{(1)Weight}

Table 2. Weight of vegetation coverage index

\begin{tabular}{|c|c|c|c|c|c|}
\hline Class & forest & grass & farm & Construction & unused \\
land & land & land & land & land \\
\hline weight & 0.38 & 0.34 & 0.19 & 0.07 & 0.02 \\
\hline
\end{tabular}

\section{(2)Calculation method}

$$
I_{\text {veg }}=\frac{A_{\text {veg }}\left(0.38 S_{f}+0.34 S_{g}+0.19 S_{a}+0.07 S_{c}+0.02 S_{u}\right)}{S_{r}}
$$

Where $A_{\text {veg }}$ is normalization coefficient of vegetation coverage index, value is 121.165124 . 


\subsubsection{Calculation Method of Water Network Denseness Index}

$I_{\text {wat }}=\frac{1}{3}\left(\frac{A_{\text {riv }} \times \text { river length }}{S_{r}}+\frac{A_{\text {lak }} \times \text { water area }}{S_{r}}+\frac{A_{\text {res }} \times \text { water resources }}{S_{r}}\right)$

Where $A_{\text {riv }}$ is normalization coefficient of river length, value is $84.3704083981 ; A_{\text {lak }}$ is normalization coefficient of water area, value is 591.7908642005; $A_{\text {res }}$ is normalization coefficient of water resources quantity, value is 86.3869548281, and $S_{r}$ is whole area of evaluated region.

\subsubsection{Weight and Calculation Method of Land Stress Index}

$I_{\text {lan }}$ means stress intensity of evaluated region, soil erosion, land desertification are involved to express land stress index. (1)Weight

Table 3. Weight of land stress index

\begin{tabular}{|c|c|c|c|c|}
\hline $\begin{array}{c}\text { Degree of } \\
\text { erosion }\end{array}$ & serious & moderate & $\begin{array}{c}\text { Construction } \\
\text { land }\end{array}$ & slight \\
\hline weight & 0.4 & 0.2 & 0.2 & 0.2 \\
\hline
\end{tabular}

\section{(2)Calculation method}

$I_{\text {lan }}=\frac{A_{\text {ero }}}{S_{r}}(0.4 \times$ severe erosion area $+0.2 \times$ moderate erosion area +

$0.2 \times$ constrction land area $+0.2 \times$ slight erosion area)

Where $A_{\text {ero }}$ is normalization coefficients of land stress index, value is 236.0435677948 .

\subsubsection{Weight and Calculation Method of Pollution Load Index}

\section{(1)Weight}

Table 4. Weight of pollution load index

\begin{tabular}{|c|c|c|c|c|}
\hline Pollution index & $\begin{array}{c}\text { sulfur } \\
\text { dioxide(SO2) }\end{array}$ & COD & $\begin{array}{c}\text { solid } \\
\text { waste }\end{array}$ & other \\
\hline Weight & 0.4 & 0.2 & 0.2 & 0.2 \\
\hline
\end{tabular}

\section{(2)Calculation method}

$I_{p d}=\frac{A_{\mathrm{SO}_{2}} \times 0.4 \times V_{\mathrm{SO}_{2}}+A_{Y F C} \times 0.3 \times V_{Y F C}}{S_{r}}+\frac{A_{C O D} \times 3 \times V_{C O D}}{P}$

Where $A_{\mathrm{SO}_{2}}$ is normalization coefficients of $\mathrm{SO}_{2}$, dust, COD, values are $0.0648660287,4.0904459321$, 4.3937397289. $V_{\mathrm{So}_{2}}$ is sulfur dioxide emission, $A_{Y F C}$ is smoke (powder) dust emission, $V_{C O D}$ is COD emission, $P$ is regional average annual rainfall .

\subsection{Evaluation on Ecological Environmental Quality}

Ecological index (EI) is used to describe, and its value range $0-100$.

\subsubsection{Weight}

Table 5. Weight of each index

\begin{tabular}{|c|c|c|c|c|c|}
\hline index & $\begin{array}{c}\text { Biological } \\
\text { richness } \\
\text { index }\end{array}$ & $\begin{array}{c}\text { Vegetation } \\
\text { coverage } \\
\text { index }\end{array}$ & $\begin{array}{c}\text { Water } \\
\text { network } \\
\text { denseness } \\
\text { index }\end{array}$ & $\begin{array}{c}\text { Land } \\
\text { stress } \\
\text { index }\end{array}$ & $\begin{array}{c}\text { Pollution } \\
\text { load } \\
\text { index }\end{array}$ \\
\hline Weight & 0.35 & 0.25 & 0.15 & 0.15 & 0.10 \\
\hline
\end{tabular}

\subsubsection{Calculation Method of Ecological Quality Index}

$\mathrm{EI}=0.35 \times$ Biological richness index +

$0.25 \times$ Vegetation coverage index +

$0.15 \times$ Water network denseness index +

(6)

$0.15 \times(100-$ Land stress index $)+$

$0.10 \times(100-$ Pollution load index $)$

Table 6 shows degree of Ecological Environmental Quality, and range of Ecological index change is always divided into 4 grades, that is not sensitive, slight change, obvious change, significant change (Table 7).

\section{Evaluation on Ecological Environmental Quality in Dongsheng District}

\subsection{Analysis on Land Use Structure}

Land cover information was extracted according to "code for classification of urban land use and planning standards of development land (GB50137-2011)" issued by Ministry of Housing and Urban-Rural Development of the People's Republic of China and General Administration of Quality Supervision, Inspection and Quarantine of the People's Republic of China, and then class the land types. Standard specifies classification should according to the main character of land use; land classification has 3 Classification Systems, that are large class, middle class and small class, including urban and rural land classification, urban construction land classification two parts, which can be divided into 10 large categories, 44 middle categories, 59 
Table 6. Degree of Ecological index

\begin{tabular}{|c|c|c|c|c|c|}
\hline degree & excellent & good & normal & poor & bad \\
\hline range & $\mathrm{EI} \geqslant 75$ & $55 \leqslant \mathrm{EI}<75$ & $35 \leqslant \mathrm{EI}<55$ & $20 \leqslant \mathrm{EI}<35$ & $\mathrm{EI}<20$ \\
\hline $\begin{array}{c}\text { conditi } \\
\text { on }\end{array}$ & $\begin{array}{l}\text { High vegetation } \\
\text { coverage, rich } \\
\text { biodiversity, } \\
\text { ecosystem is } \\
\text { stability, the most } \\
\text { suitable degree for } \\
\text { human life }\end{array}$ & $\begin{array}{l}\text { vegetation coverage and } \\
\text { biodiversity is well, it is } \\
\text { suitable for people to } \\
\text { live. }\end{array}$ & $\begin{array}{l}\text { The vegetation coverage is } \\
\text { moderate, the biological } \\
\text { diversity is general, and } \\
\text { suitable for human life, but } \\
\text { sometimes there is some } \\
\text { limitation for the survival of } \\
\text { human beings. }\end{array}$ & $\begin{array}{l}\text { Poor vegetation } \\
\text { cover, severe } \\
\text { drought and little } \\
\text { rain, fewer species, } \\
\text { there are restricting } \\
\text { factors }\end{array}$ & $\begin{array}{l}\text { The condition is poor, } \\
\text { most of land are Gobi, } \\
\text { desert, saline alkali land, } \\
\text { human's survival } \\
\text { environment is poor }\end{array}$ \\
\hline
\end{tabular}

Table 7. Range of Ecological index change

\begin{tabular}{|c|c|c|c|c|}
\hline level & Not sensitive & Slight change & Obvious change & significant change \\
\hline Change value & $|\Delta \mathrm{EI}| \leq 2$ & $2<|\Delta \mathrm{EI}| \leqslant 5$ & $5<|\Delta \mathrm{EI}| \leqq 10$ & $|\Delta \mathrm{EI}|>10$ \\
\hline description & $\begin{array}{l}\text { There was no obvious } \\
\text { change in ecological } \\
\text { environment }\end{array}$ & $\begin{array}{l}\text { If } 2<\Delta \mathrm{EI} \leqslant 5 \text {, the } \\
\text { ecological environment is } \\
\text { slightly going better; if } \\
-2>\Delta \mathrm{EI} \geq-5 \text {, going poor. }\end{array}$ & $\begin{array}{c}\text { If } 5<\Delta \text { EI } \leqslant 10 \text {, the } \\
\text { ecological environment is } \\
\text { obviously going better; If } \\
-5>\Delta \text { EI } \geq-10 \text {, obviously } \\
\text { going poor. }\end{array}$ & $\begin{array}{c}\text { If } \Delta \mathrm{EI}>10 \text {, the ecological } \\
\text { environment status is } \\
\text { significantly better; If } \Delta \\
\mathrm{EI}<-10 \text {, then environment } \\
\text { status is significantly } \\
\text { going bad. }\end{array}$ \\
\hline
\end{tabular}

Table 8. Ecological environment status and change in Dongsheng district during 2005-2014.

\begin{tabular}{|c|c|c|c|c|c|c|}
\hline time & $\begin{array}{c}\text { Biological richness } \\
\text { index }\end{array}$ & $\begin{array}{c}\text { Vegetation } \\
\text { coverage index }\end{array}$ & $\begin{array}{c}\text { Water network } \\
\text { denseness index }\end{array}$ & Land stress index & $\begin{array}{c}\text { Pollution load } \\
\text { index }\end{array}$ & EI \\
\hline 2005 & 83.95 & 20.40 & 31.39 & 39.80 & 61.59 & 52.06 \\
\hline 2008 & 75.89 & 22.46 & 26.21 & 39.01 & 27.75 & 52.48 \\
\hline 2011 & 75.23 & 22.28 & 27.40 & 39.31 & 55.35 & 49.58 \\
\hline 2014 & 74.64 & 22.15 & 26.77 & 31.04 & 29.12 & 53.11 \\
\hline
\end{tabular}

small categories.10 large categories contain construction land, water land, residential land, public management and public service land, land for commercial use, industrial land, warehouse land, transportation use, public facilities, green space. Land types used in this paper are grassland, forest land, farmland, water area, urban land, construction land, unused land. Then draw these objects on the basis of Arcgis platform, the results are shown in figure1, figure 2.

\subsection{Evaluation on Ecological Environment}

On the basis of "Technical Criterion for Ecosystem Status Evaluation", combine with table1-7, put the area of difference land use types into the formula, finally can get to ecological quality index during 2005-2014 (table 8).

The evaluation results show that biological richness of Dongsheng at the high level in 2005, the value is 83.95 ; biological richness index has great changes during 2005-2014, down from 83.95 in 2005 to 74.64 in 2014, the main reason is the reduce of water wetland area, the cultivated area (Figure 2), the weight of water area reached 0.28 to the biological richness index , and most important is Dongsheng district is a water shortage region, large changes in water area influence biological richness index significantly. Dongsheng district is the economy, politics and culture center of Erdos city, the population is relatively concentrated, so ecological types like farmland, woodland and grassland possess high proportion in the total area which was $10.99 \%, 20.89 \%$, and $23.05 \%$. In addition, the reduction of unused land area is consistent with the increasing trend of the construction land area, which indicates that the economic construction intensity of Dongsheng district is larger in the past ten years, the human activities are frequent, and the ecological 
environment pressure is heavy. The maximum value of vegetation coverage is the highest in 2014 with22.15.Vegetation cover index increased from 20.40 to 22.15 between 2005 and 2014, an increase of 1.75 . Water density index decreased from 31.39 in 2005 to 26.77 in 2014 , reduced by 4.62 .This is mainly because the water area land area is consistent with the increasing trend of the construction land area, which indicates that the economic construction intensity of Dongsheng district is larger in the ten years, the human activities are frequent, and the ecological environment pressure is heavy. The maximum value of vegetation coverage is the highest in 2014 was 22.15. Vegetation cover index increased from 20.40 to 22.15 between 2005 and 2014, an increase of 1.75. Water density index decreased from 31.39 in 2005 to 26.77 in 2014 , reduced by 4.62 . This is mainly because the water

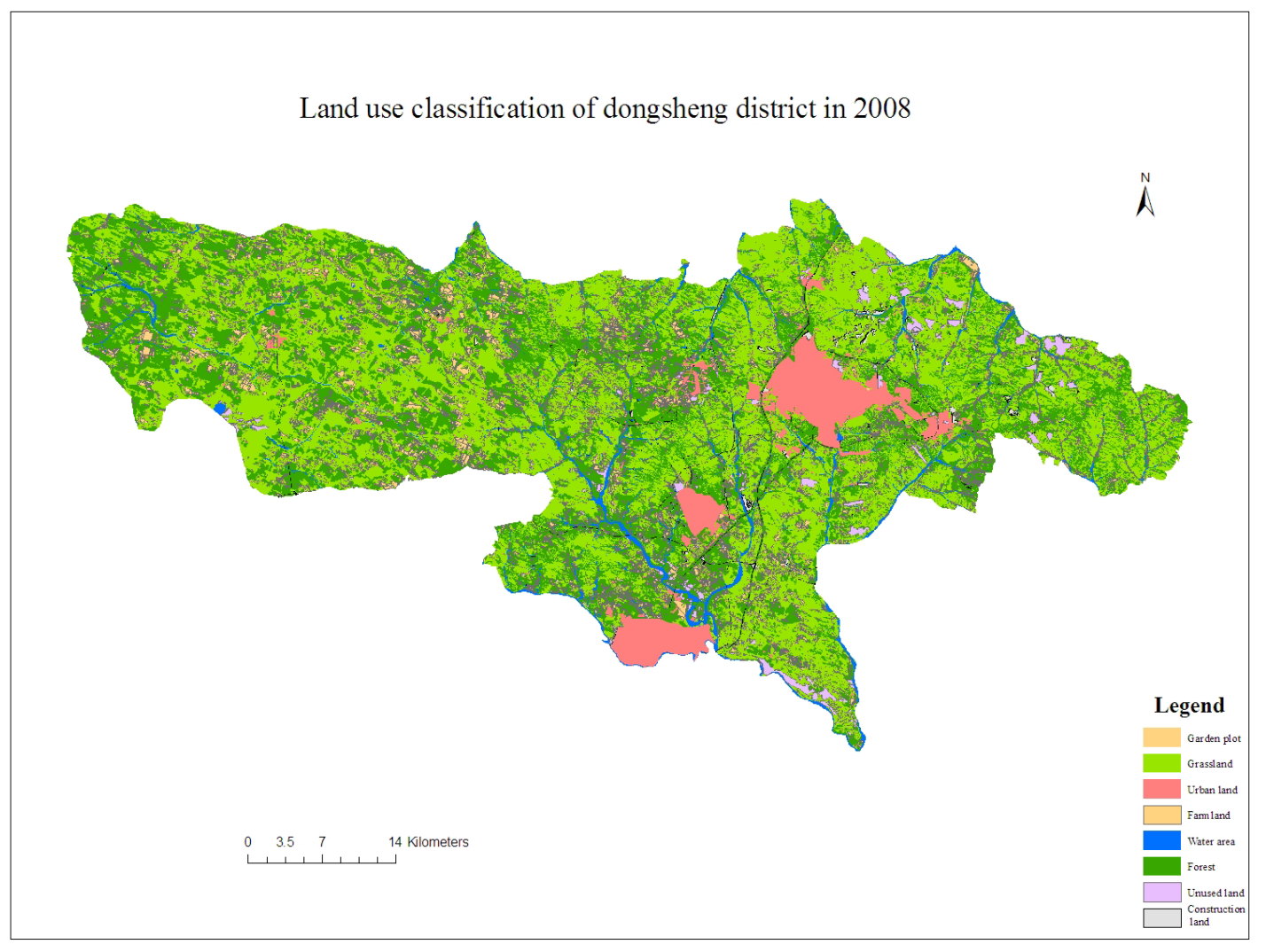

Fig. 1. Remote sensing interpretation of land use / cover of Dongsheng district in 2014.

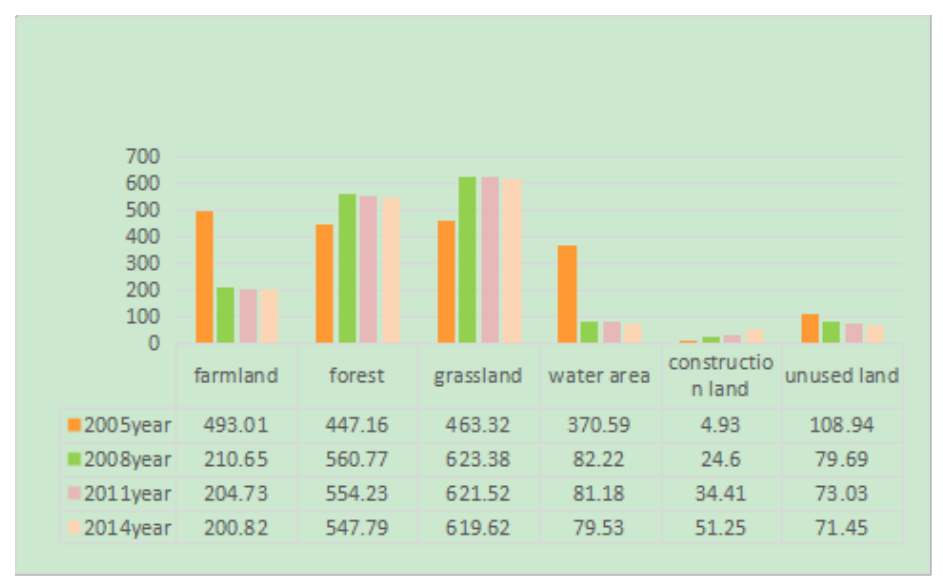

Fig. 2. Area of various land use types 
area decreased significantly from 2014 to 2005 , from $79.53 \mathrm{~km}^{2}$ (2005) to $370.59 \mathrm{~km}^{2}$ (2014).Water density index can reflect the regional ecological environment distribution and climatic characteristics, the more water density index value is large, the more suitable for human to live. When calculating land degradation index, soil erosion degree was mainly observed. The types of soil erosion were divided into mild, moderate and severe erosion. Mild soil erosion area in Dongsheng region decreased from $767.59 \mathrm{~km}^{2}$ in 2005 to $585.33 \mathrm{~km}^{2}$, decreased $182.26 \mathrm{~km}^{2}$ and moderate erosion area were $664.02 \mathrm{~km}^{2}, 528.71 \mathrm{~km}^{2}, 456.98 \mathrm{~km}^{2}, 398.67 \mathrm{~km}^{2}$, severe erosion area reduced from $342.11 \mathrm{~km}^{2}$ (2005) to $313.33 \mathrm{~km}^{2}$ (2014).The erosion area continued to decrease, land degradation index has an upward trend, and its value is 39.80 in 2005 decreased to 31.04 in 2014.This is mainly attributed to the implementation of the policy of returning farmland to forest and grassland after the second survey of land resources in 2008. The pollution load index is mainly composed of $\mathrm{SO}_{2}, \mathrm{COD}$ and rainfall to calculated, $\mathrm{SO}_{2}$ emissions in 2005, 2014 were 42765 tons, 20217 tons, and average annual rainfall was $220.3 \mathrm{~mm}$, $386.9 \mathrm{~mm}, 252.3 \mathrm{~mm}$, and $450.8 \mathrm{~mm}$.

\section{Conclusion}

The evaluation of land ecological environmental quality in Dongsheng district results (Table 8) shows that the ecological environment quality of Dongsheng area belongs to the "normal", the vegetation coverage is moderate, the biological diversity is general, and suitable for human life, but sometimes there is some limitation for the survival of human beings. From 2005 to 2014, Ecological index is 52.06, 52.48, 49.58, 53.11, from the overall trend, the land ecological environment quality of Dongsheng area improved year by year, the main reason is due to the increase of vegetation index and land degradation, pollution load index decreased year by year, and the average contribution rate of these indexes to Ecological index was $16.86 \%, 28.8 \%, 33.77 \%$. According to table7, the value of Ecological index change is 0.42 during 2005-2008 with no significant changes. In 2008-2011, $\Delta \mathrm{EI}$ is -2.9 , in interval of $-2>\Delta \mathrm{EI} \geq-5$, the ecological environment is slightly worse. During the period of 2011-2014, $|\Delta \mathrm{EI}|$ is 3.53, belonging to $2<\Delta \mathrm{EI} \leq 5$, ecological environment is slightly better. But from 2005 to $2014,|\Delta \mathrm{EI}|$ is 1.05 , indicating that the quality of land ecological environment has not changed significantly, the land ecological environment is better, the structure of land ecosystem is more complete, and the land ecosystem service function is basically perfect.

\section{References}

[1] Song J, Wang H, Wang F. Research progress of ecological environment quality assessment and methods review. Environmental Science \& Technology, 2013, 36: 448-453.

[2] Zhou H. Study on ecological environmental quality as assessment index system of Xinjiang. China environmental science, 2000, 20(2):150-153.

[3] Zheng X, Wang A. Study on the integrated assessment of regional ecological environmental quality based on RS \& GIS for Shandong Province. Acta Scientiae Circu Mstantiae, 2000, 20(4): 489-493.

[4] Liu H. Ecological environment evaluation research in Beijing based on RS, GIS. Capital Normal University, 2008.

[5] Liu J, Li X, Gao L. Application of RS technologies in monitoring and synthetically evaluation on the eco-environment in Xinjiang. Arid Land Geography, 2004, 27(4):508-511.

[6] Xiong Y, Wang K, Huang D. Eco-environmental synthetic evaluation based on GIS tecnology in Hunan Province. Journal of Soil and Water Conservation, 2004, 18(5): 174-178.

[7] Cui X, Liu G. Researches on urban ecosystem environmental assessment in Huhhot City. Areal Research and Development, 2011, 30(6): 79-83.

[8] Ma R. Evaluation on eco-environmental quality of Hainan Island. Rural Eco-Environment, 2000, 16(4):11-14, 32.

[9] Huang B, Wang S, Yang H. City eco-environment quality assessment based on GIS and RS. Journal of Tongji University (Natural Science), 2009, 37(6):805-809.

[10] Ministry of Environmental Protection of the People's Republic of China. Technical Criterion for Ecosystem Status Evaluation (HJ192-2015). Beijing, China Environmental Science Press, 2015. 